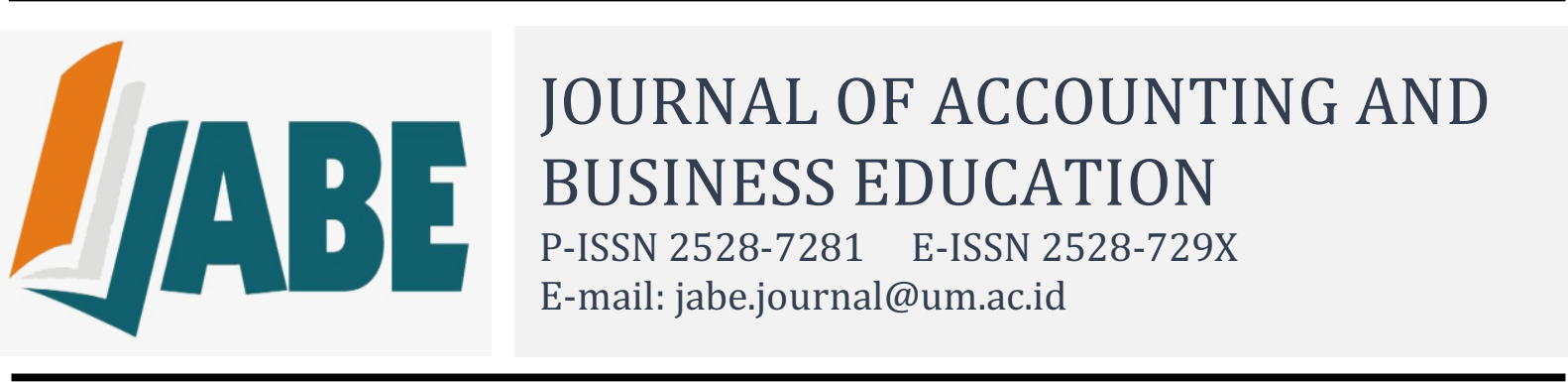

\title{
Money and Unethical Behavior of Accounting Students
}

\author{
Luh Gede Krisna Dewi \\ Ayu Aryista Dewi \\ Universitas Udayana \\ krisna_penindra@yahoo.com
}

\begin{abstract}
Financial fraud involving the accounting profession lower public confidence in the accounting profession and the presentation of financial statements. The need for early detection of the factors causing a person to commit an unethical behavior is increasing. Accounting students as individuals who will enter the workforce and become accounting professionals are expected to get accounting ethics education correctly. This study aimed to analyze the relationship among the love of money, the machiavellian behavior, the unethical behavior, and gender as demographic variables. Respondents were active undergraduate students in Accounting Department. The sampling technique used purposive sampling with sample amounted to 234 respondents. Data collection was conducted through questionnaires containing 34 items of questions related to the behavior of love of money, Machiavellian, and unethical behavior. The results found that Machiavellian behavior can mediate the influence of love of money on the unethical behavior of Accounting students. Men tend to choose to take risks in action than women, so this research indicated that gender as demographic variables can also affect the relationship of love of money to unethical behavior.
\end{abstract}

Keywords: Love of money, machiavellian, gender, unethical behavior

\section{INTRODUCTION}

Since there are a lot of rampant cases involving accounting profession, an ethical behavior of an accountant has attracted public attention. In 2001, the case of Enron and Worldcom is the initial milestone which reminds us about the importance of moral and ethical behavior. This case involves the act of the corporate leader in maximizing profit, maintaining the position, manipulating other parties for the sake of personal gain, doing an opportunistic act in cooperation, and ignoring the moral value to gain profit (Pekdemir and Turan, 2015). Some cases involving public accounting influence the perception of financial statement's user toward the reliability of financial statement.

Normadewi (2012) states the ethical behavior determines the position of accountant in society. Murtanto and Marini (2003) state the education is the factor which influence people to behave ethically. The importance of professional ethic for accountant should be embedded in 
early stage for character and moral building. The accountant students that will become professional accountant are expected to get an ethical education correctly. Elias (2010) says that the accountant students will be a professional accountant in the future, the right ethical education will benefit his profession in the long term. Herman (2016) also states that the understanding and perception about the ethical profession of accountant is very important to their profession in the future.

There are many factors that influence the ethical profession. Based on the organizational behavior theory, the individual perception is affected by the factors which derive from the individual, environment, and the perceived object (Robbins and Judge, 2008). One of the factors which derive from an individual is the love of money. Based on Tang (1992), love of money is an individual's subjectivity about money. Pekdemir and Turan (2015) define the love of money as an individual's penchant for money (fond of money). The concept arises because of the importance function of money that money is the benchmark of income and welfare and every individual has a different perception about money (Tang, 1992).

Griffin and Ebert (2006) explain that ethical behavior is a behavior that conforms to social norm and related to the right behavior. Whereas the behavior that is not appropriate with the definition above considered as unethical behavior. The emerging of unethical behavior is initiated by the poor perception of accountant students. Wouters et. al (2014) says that the unethical behavior is varied from the small infraction (longer break time, absence, and creating destructive issue) to the criminal act (corruption, Embezzlement, and fraud). Vardi and Wiener (1996) state that the unethical behavior is an action conducted by the public service that violate and contradict with (a) norm and expectation of an organization and (b) the basic social value, moral, and standard of good behavior.

Tang and Chiu (2003) state love of money concept is related to the greed. They found out that the employees in Hongkong which have a high level of love of money work less satisfactory compare to their fellows. Chen and Tang (2006) show the relationship causes an unethical behavior. The study of Tang and Chiu (2003) stated that there were an increasing number of thought which considered money as the tool to motivate, symbol of success, and money is very important to gain some wealth. Those factors create the concept of love of money behavior. Moreover, money also considered as the power control and the root of criminality. The result of the study showed that the love of money behavior significantly influences to the ethical perception. In their study, it was found out that there are significant differences about ethical behavior based on the gender differences. 
Pradani and Prastiwi (2014) explain the relation between love of money behavior and the ethical perception of accounting students. Their study showed that demographic factors (education level, social status, and ethnic background) did not affect the love of money behavior. Only gender that affected the ethical perception of accounting students, but it did not affect the love of money behavior. The opposite result was gotten by Charismawati (2011) who stated that there was a relation between the level of love of money and the ethical perception of accounting students. Gender did not affect the love of money behavior, but it affected the ethical perception of accounting students. Basri (2015) tested the effect of gender, religiosity, and love of money behavior toward the ethical perception of tax evasion of accounting students. This study found out that gender did not affect the love of money behavior and the ethical perception of tax evasion, and the love of money behavior affected the ethical perception of accounting students.

Another factor that affect the ethical perception is Machiavellianism. The concept of Machiavellianism emerges from the idea of a politician from Firenze Italia named Niccolo Machiavelli. The idea was written in the book entitled IL Principe (the ruler). The book reveals the act to get, expand, and use power maximally. The book also explains the way to perpetuate the authority illegaly.

The machiavellian is a behavior that is associated with a bad action and uphalize all ways to get and perpetuate the power (Cristie and Geis, 1970). Generally, machiavellian claims that the regulations and rules that reflect the unethical behavior are more delighted than the fair regulations and rule (Pekdemir and Turan, 2015). Based on Cristie and Geis (1970), machiavellian behavior is defined in three different dimensions, they are a violation and manipulation, cynicism, and conventional moral offense. Tang and Chiu (2003) conducted a study that examines the effect of love of money behavior toward the level of machiavellian. The study found out that the higher the love of money level, the higher the level of machiavellian. This study was in line with the study of Fuad (2013) that found out about the relation between the love of money behavior to the ethical thought and machiavellian behavior. The study of Aziz and Taman (2015) revealed that love of money behavior and machiavellian behavior affected the ethical perception of accounting students.

Some researchers use demographic as the factor that affect the love of money, Machiavellian, and unethical behavior of students. Demographic factor that is frequently used as a construction in research is gender. Charismawati (2011) found out that gender did not affect the love of money level, but it affected the ethical perception of students. Normadewi (2012) in her research found that gender did not affect both the love of money behavior and 
the ethical perception of students. Tang et al. (2000) in their research found out that the female employees have a tendency to prioritize money. Some research found out that the female has more ethical behavior than the male. However, other research showed that there were no significant differences between the ethical behavior of female or male students. Pekdemir and Turan (2015) also included the demographic such as gender, age, experience, education level, and ethnic intervention as the factor that affected the level of love of money, Machiavellian behavior, and unethical behavior of students. The result of the study stated that gender affected the level of unethical behavior. The male tended to have more unethical behavior than the female.

This study aimed to analyze the effect of 1) Machiavellian behavior in mediating the relation between love of money and unethical behavior, 2) the high level of love of money behavior toward the machiavellian behavior, 3) the high level of love of money behavior toward the unethical behavior, 4) the high level of machiavellian behavior toward the unethical behavior, and 5) gender toward the love of money, machiavellian, and unethical behavior of students.

\section{LITERATURE REVIEW AND HYPOTHESES}

Expectation theory from Victor Vroom proposes an individual will be motivated to behave in specific way based on the expected result. A perception plays an important role in this theory because the perception emphasizes on cognitive ability to anticipate the consequences. Motivation theory states that employees will be motivated to do maximum performance when they assure that their performance is paid off. The good performance will resulted the organizational rewards and those rewards will satisfy the employees (Robbins and Judge, 2008)

Generally, expectation theory can be used to predict the behavior in every situation in which there are two or more alternative to be made (Kreitner and Kinicki, 2003 dalam Normadewi, 2012). As an example, the expectation theory can be used to predict the ethical perception of students in relation to the love of money level by identifying the result obtained if an individual considers money is more important than ethical behavior and whether the result obtained has fulfilled the individual needs.

Ethic is a guideline to behave properly based on the culture, moral, and religion. Ethic is a moral principle and behavior which become the cornerstone of an individual, so that they will be considered to have done commanedable deed (Munawir dalam Marwanto, 2007). Ethic directs an individual to moral behavior. Moral or morality is associated the good or bad 
behavior. While ethic is a study about moral, system, or code behavior. The individual ethic can affect the individual perception.

Unethical behavior has been studied in some of field, such as business ethic, organization of psychology, and criminology. The unethical behavior occurs from the low ethical perception of students. The unethical work behavior is varied from the small infraction, such as longer break time, absence, and creating destructive issue, to the criminal act, such as corruption, Embezzlement, and fraud (Wouters et. al, 2014). Based on Vardi ana Wiener (1996) unethical behavior is an act that done by public service to violate (a)norm and expectation of organization and (b) basic social value, moral, and the standard of wrong and good doing. Moore et. al (2012) revealed eight dimensions of unethical behavior, they are moral justification, euphemistic labeling, favorable comparison, transfer of responsibility, diffusion of responsibility, distortion of consequence, dehumanization, and attribution of mistake. Chen and Tang (2006) stated five dimensions of unethical behavior, they are resource abuse, non-wistle blowing, embezzlement, corruption, and fraud.

Tang (1992) introduces the concept of the love of money for psychological literature. This concept measures the subjectivity of individual toward money. Tang and Chiu (2003) state that the love of money concept is closely related to the greed concept. Chen and Tang (2206) shows that the love of money can create the unethical behavior.

Machiavellianism concept emerges from the politician from Firenze Italy named Niccolo Machiavelli. The thought that is written in book entitled Il Principe (the ruler) reveals about the act to get, expand, and use power maximally. Based on Cristie and Geis (1970), machiavellian behavior defines in three different dimension, they are support violation and manipulation, cynical act, and violation of conventional moral. They define machiavellian behavior as an act based on the policy, manipulation, exploitation, and intrigue without traditional virtue of trust, honor, and courtesy. Some of research used demographic as a factor that affect the love of money, machiavellian, and unethical behavior. A demographic factor that is mostly constructed in research is gender. The research of Charismawati (2011) found out that gender did not affect the love of money but it affected the ethical perception of students. While Normadewi (2012) found out that gender did not affect the love of money and the ethical perception of students. Based on the aforementioned explanation, the hypothesis of this research is:

$\mathrm{H}_{1}$ : Machiavellian behavior mediates the relation between the love of money and unethical behavior of students

$\mathrm{H}_{2}$ : The high level of the love of money increases machiavellian behavior of students. 
$\mathrm{H}_{3}$ : The high level of the love of money increases unethical behavior of students.

$\mathrm{H}_{4}$ : The high level of machiavellian behavior increases unethical behavior of students.

$\mathrm{H}_{5 \mathrm{a}}$ Gender affects the love of money of students.

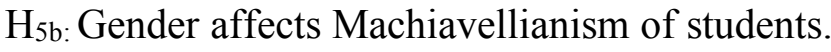

$\mathrm{H}_{5 \mathrm{c}}$ Gender affects the unethical behavior of students.

\section{METHODS}

This study was conducted in Faculty of Economy and Business Universitas Udayana (Unud). The population was 663 undergraduate students of Accounting major that were still studying. The sampling was done through purposive sampling, the number of sample was 234 respondent. The data collecting was survey through questionnaire, by giving some questions and statements to the respondents (Gendro, 2011)

The love of money variable (LOM) was measured by adopting the trust and behavior scale (Furnham, 1984), the money ethic scale (Tang, 1995), and the importance of money scale (Mitchell, 1998). Twenty questions was given to the respondents. The questions included five factors, they are motivation factor (5 items), importance factor (5 items), wealthy (4 items), power and success (4 items), and crime ( 2 items). The machiavellian variable (MV) was measured with seven items of questions adopted from the machiavellian behavior scale used by Valentine and Fleischman (2003). The unethical behavior scale was measured by replicate the instrument used by Chen and Tang (2006) and Wouters et. al (2014). While gender referred to Pekdemir and Turan's research (2015) by using dummy variable, 1 was man and 2 was woman.

There were two instrument in this study. The first, the students completed the demographic information to know their gender. The second, the questionnaire that consisted of 34 item related to the love of money, machiavellian, and unethical behavior. The data testing was done by conducting validity and reliability of instrument using coefficient correlation Pearson and coefficient Cronbach Alpha. The hypothesis was tested using SPSS programme by multiple regression analysis to test the effect of independent variable to dependent variable. While the effect of mediation variable was tested using path analysis.

\section{RESULTS}

The data has been tested through validity and reliability testing. The result showed that all the instruments and research constructs was valid and reliable. This study has fulfilled the test requirements of the classical assumption analysis that is not bias. The hypothesis using 
several structures to test each independent variable, and examine the effect of mediating variables to the dependent variable. The test of Machiavellian in mediating the effects of the love of money toward unethical behavior (Hypothesis 1) is done by looking at indirect relationship that is formed from two research model that are structures I and III. Hypothesis 2 and Hypothesis 5c which examine the effect of the love of money and gender in toward machiavellian behavior described in the structure I. Hypothesis 3, Hypothesis 4 and 5a, which examine the effect of the love of money, Machiavellian, and gender on the unethical behavior described in structure III. While Hypothesis $5 \mathrm{~b}$ which examines the effect of gender toward the love of money described in structure II.

\section{Structure Model Test I}

The result on the effect of gender and the love of money toward machiavellian begavior using SPSS was shown as follow

Table 6. Multiple Linier Regression analysis

\begin{tabular}{|c|c|c|c|c|c|c|}
\hline \multirow{2}{*}{\multicolumn{2}{|c|}{ Model }} & \multicolumn{2}{|c|}{$\begin{array}{c}\text { Unstandardized } \\
\text { Coefficients }\end{array}$} & \multirow{2}{*}{$\begin{array}{l}\text { Standardized } \\
\text { Coefficients } \\
\text { Beta }\end{array}$} & \multirow[b]{2}{*}{$t$} & \multirow[b]{2}{*}{ Sig. } \\
\hline & & $B$ & Std. Error & & & \\
\hline \multirow[t]{3}{*}{1} & (Constant) & 9.717 & 1.868 & & 5.201 & .000 \\
\hline & Jenis Kelamin & -1.205 & .480 & -.152 & -2.510 & .013 \\
\hline & LOM & .220 & .028 & .480 & 7.920 & .000 \\
\hline
\end{tabular}

a. Dependent Variable: MCV

The table was interpreted as follow :

$$
\begin{array}{ll}
\mathrm{MCV} & =\alpha+\mathrm{b} 1 \mathrm{JK}+\mathrm{b} 2 \mathrm{LOM} \ldots \ldots \ldots \ldots \ldots \ldots \\
\mathrm{MCV} & =9,717-1,205 \mathrm{JK}+0,220 \mathrm{LOM}+\mathrm{e}
\end{array}
$$

\section{T - test (Structure Model I )}

$\mathrm{T}$ test was used to determine the effect of partially independent variable on the dependent variable. In this study was the effect of gender and the love of money toward machiavellian behavior. There was a significant value $\mathrm{T}$ of each variable on the SPSS output with level of significance $0.05(\alpha=5 \%)$. Based on Table 6 above, it could be seen that the value for the variable gender significance of 0.013 . When it compared with the value of 0.05 then the value is smaller $(0.013<0.05)$. This means that $\mathrm{H} 5 \mathrm{c}$ was accepted, the gender variable effect on behavior. There was a significant value of machiavellian behavior toward the love of money 0.000 . When it compared with the value of 0.05 then the value is smaller $(0.000<0.05)$. This means that $\mathrm{H} 2$ was accepted, the love of money affects the machiavellian behavior.

\section{The coefficient of determination test $\left(R^{2}\right)$}

The coefficient of determination is analyzed to see how far the model's ability to explain 
variations in the dependent variable. Based on Table 7 adjusted R-square of 0.207 indicates that $20.7 \%$ of the variation of the machiavellian value can be explained by gender and the love of money while the remaining $79.3 \%$ is explained by variable outside the model

Table 7. The coefficient of determination test (structure I)

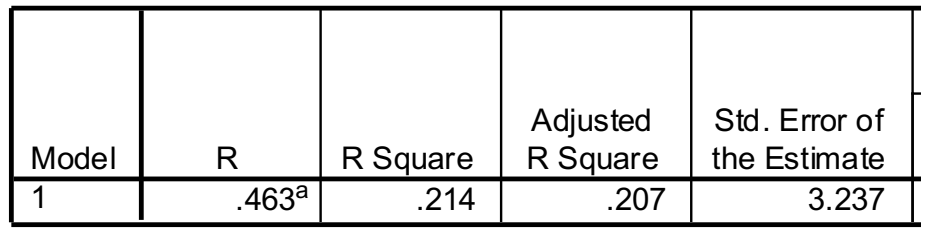

a. Predictors: (Constant), LOM, Jenis Kelamin

b. Dependent Variable: MCV

\section{Test Structure Model III}

Statistical hypothesis was used to determine the effect of gender, the love of money, and Machiavellian toward the unethical behavior, using SPSS obtained the following results

Table 8. Test Structure Model III

\begin{tabular}{|ll|r|r|r|r|r|}
\hline \multirow{2}{*}{ Model } & \multicolumn{2}{|c|}{$\begin{array}{c}\text { Unstandardized } \\
\text { Coefficients }\end{array}$} & \multicolumn{2}{c|}{$\begin{array}{c}\text { Standardized } \\
\text { Coefficients }\end{array}$} & & \\
\cline { 2 - 5 } & & \multicolumn{1}{|c|}{$\mathrm{B}$} & Std. Error & \multicolumn{1}{c|}{ Beta } & \multicolumn{1}{c|}{$\mathrm{t}$} & \multicolumn{1}{c|}{ Sig. } \\
\hline 1 & (Constant) & .680 & 3.179 & & .214 & .831 \\
& Jenis Kelamin & -1.873 & .783 & -.153 & -2.392 & .018 \\
& LOM & .155 & .051 & .218 & 3.063 & .002 \\
& MCV & .349 & .106 & .226 & 3.297 & .001 \\
\hline
\end{tabular}

a. Dependent Variable: UE

The result was interpreted as follow:

$$
\begin{aligned}
& \mathrm{UE}=\alpha+\mathrm{b} 1 \mathrm{JK}+\mathrm{b} 2 \mathrm{LOM}+\mathrm{b} 3 \mathrm{MCV} \ldots \ldots \ldots \ldots \ldots \ldots \\
& \mathrm{UE}=0,680-1,873 \mathrm{JK}+0,155 \mathrm{LOM}+0,349 \mathrm{MCV}+\mathrm{e}
\end{aligned}
$$

\section{T test (Model Structure III)}

$\mathrm{T}$ test was used to determine the effect of partially independent variable on the dependent variable. In this study was the effet of gender, the love of money, machiavellian toward the unethical behavior. There was a significant value $t$ of each variable on the SPSS output with a significance level of $0.05(\alpha=5 \%)$. Based on Table 8 above, it was known that significant value for the variable gender at 0.018 . When it compared with the value of 0.05 then the value was smaller $(0.018<0.05)$. This meant that $\mathrm{H} 5 \mathrm{a}$ was accepted, the gender variable affects the unethical behavior. There was also significant value for the love of money variable to 0,002 . When it compared with the value of 0.05 then the value was smaller $(0.002<0.05)$. This meant that the H3 was accpeted, the love of money 
variable affects the unethical behavior. There was significant value for the Machiavellian variable of 0.001 . When it compared with the value of 0.05 then the value was smaller $(0.001$ $<0.05$ ). This meant that the $\mathrm{H} 4$ was accepted, the machiavellian variable affects the unethical behavior.

\section{The coefficient of determination test $\left(R^{2}\right)$}

The coefficient of determination is analyzed to see how far the model's ability to explain variations in the dependent variable. Based on Table 9 adjusted R-square of 0.138 indicates that $13.8 \%$ of the variation value of unethical behavior can be explained by gender, the love of money, and Machiavellian while the remaining $86.2 \%$ is explained by variables outside the model.

Table 9.The coefficient of determination test (structure III)

\begin{tabular}{|l|r|r|r|r|}
\hline & & & & \\
Model & $\mathrm{R}$ & $\mathrm{R}$ Square & $\begin{array}{c}\text { Adjusted } \\
\text { R Square }\end{array}$ & $\begin{array}{c}\text { Std. Error of } \\
\text { the Estimate }\end{array}$ \\
\hline 1 & $.386^{\mathrm{a}}$ & .149 & .138 & 5.211 \\
\hline
\end{tabular}

a. Predictors: (Constant), MCV, Jenis Kelamin, LOM

b. Dependent Variable: UE

In this study, there was mediating variable namely Machiavellian. The function was to mediate the influence of independent variables on the dependent variable. The test used path analysis. Path analysis is the development of statistical regression. A variable can be regarded as an intervening variable (mediation) when it meets the criteria, ie indirect relationships outweigh the direct relationship (Ghozali, 2013). The path coefficients calculated by making two structural equation, namely the regression equation showing the relationship hypothesized formed from structural equation I and III structures.

\section{Structural equation I}

Based on Table 10, it can be seen the significance value of gender that was 0,013 , as well as the significance value of the love of money that was 0,000 . This meant that gender and the love of money affect Machiavellian. The resulting structural regression equation is: $\mathrm{Y}=-0,152 \mathrm{JK}+0,480 \mathrm{LOM}+\mathrm{e}_{1}$

Based on Table 10 it can be seen the values of coefficients standardized beta of -0.152 for gender toward Machiavellian on the value of the path P2. The standardized Coefficients value beta was 0.480 for the love of money toward the machiavellian value of the path P3. 
Table 10. The Significant of Structue Equation I

\begin{tabular}{|rl|r|r|r|r|r|}
\hline \multirow{2}{*}{ Model } & \multicolumn{2}{|c|}{$\begin{array}{c}\text { Unstandardized } \\
\text { Coefficients }\end{array}$} & \multicolumn{2}{c|}{$\begin{array}{c}\text { Standardized } \\
\text { Coefficients }\end{array}$} & & \\
\cline { 3 - 5 } & & \multicolumn{1}{|c|}{$\mathrm{B}$} & Std. Error & \multicolumn{1}{|c|}{ Beta } & \multicolumn{1}{c|}{ Sig. } \\
\hline 1 & (Constant) & 9.717 & 1.868 & & 5.201 & .000 \\
& Jenis Kelamin & -1.205 & .480 & -.152 & -2.510 & .013 \\
& LOM & .220 & .028 & .480 & 7.920 & .000 \\
\hline
\end{tabular}

a. Dependent Variable: MCV

\section{Structural Equation III}

Based on Table 11 showed that the gender variable has a value of minus which means a negative effect on the unethical behavior variable, while the love of money varable and Machiavellian has a positive effect on the unethical behavior. The structural equation regression produced is as follows.

$\mathrm{Z}=-0,153+0,218 \mathrm{LOM}+0,226 \mathrm{MCV}+\mathrm{e} 2$

Table 11. Significance of Equation Structure III

\begin{tabular}{|c|c|c|c|c|c|c|}
\hline \multirow{2}{*}{\multicolumn{2}{|c|}{ Model }} & \multicolumn{2}{|c|}{$\begin{array}{c}\text { Unstandardized } \\
\text { Coefficients }\end{array}$} & \multirow{2}{*}{$\begin{array}{c}\begin{array}{c}\text { Standardized } \\
\text { Coefficients }\end{array} \\
\text { Beta }\end{array}$} & \multirow[b]{2}{*}{$\mathrm{t}$} & \multirow[b]{2}{*}{ Sig. } \\
\hline & & B & Std. Error & & & \\
\hline \multirow[t]{4}{*}{1} & (Constant) & .680 & 3.179 & & .214 & .831 \\
\hline & Jenis Kelamin & -1.873 & .783 & -.153 & -2.392 & .018 \\
\hline & LOM & .155 & .051 & .218 & 3.063 & .002 \\
\hline & MCV & .349 & .106 & .226 & 3.297 & .001 \\
\hline
\end{tabular}

a. Dependent Variable: UE

The coefficients standardized value Beta of -0.153 was a path value or paths $\mathrm{P} 1$ of the variable gender toward the unethical behavior. 0.218 was the value of the path $\mathrm{P} 4$ the love of money toward the unethical behavior. 0.226 was the value of path $\mathrm{P} 5$ which was Machiavellian toward the unethical behavior. A variable meets the criteria as an intervening variable (mediation) if the value of the indirect relationship is greater than a direct relationship. Table 12 describes the test results of path analysis.

Table 12. Path Analysis Test Result

\begin{tabular}{lcl}
\hline \multicolumn{1}{c}{ Information } & Beta (error) & Analysis \\
\hline Direct effect of LOM to UE & 0.051 & $\begin{array}{l}\text { Machiavellian mediates the } \\
\text { effect of the love of money } \\
\text { toward the unethical } \\
\text { behavior }\end{array}$ \\
$\begin{array}{l}\text { Indirect effect of LOM to MCV } \\
\text { to UE }\end{array}$ & $0,028^{*} 0,106=$ \\
0,108 & a
\end{tabular}

Based on table 12, the beta value (error) of indirect effect of the love of money toward machiavellian to the unethical behavior $(0.108)$ was greater than the direct effect behavior 
(0.051) so it can be concluded that the macheviallian mediates the effects of the love of money toward the unethical behavior. Sobel test can be used to test the significance of the effect of mediating variables. The significance value of Sobel test is $p<0.05$ then the mediating variables had a significant effect as a mediating variable. The $p$ value 0.035 is less than 0.05 , which means $\mathrm{H}_{1}$ was accepted, that there was an effect of the love of money to the unethical behavior through Macheviallian behavior. 


\section{Structure Model Test II}

Statistical hypothesis testing which was to determine the effect of gender on the love of money, by using SPSS obtained the following results:

Table 13. Structure Model Test II

\begin{tabular}{|c|c|c|c|c|c|c|}
\hline \multirow{2}{*}{\multicolumn{2}{|c|}{ Model }} & \multicolumn{2}{|c|}{$\begin{array}{c}\text { Unstandardized } \\
\text { Coefficients }\end{array}$} & \multirow{2}{*}{$\begin{array}{c}\text { Standardized } \\
\text { Coefficients } \\
\text { Beta }\end{array}$} & \multirow[b]{2}{*}{$\mathrm{t}$} & \multirow[b]{2}{*}{ Sig. } \\
\hline & & B & Std. Error & & & \\
\hline & (Constant) & 60.450 & 1.921 & & 31.464 & .000 \\
\hline & Jenis Kelamin & 4.650 & 1.091 & .270 & 4.263 & .000 \\
\hline
\end{tabular}

a. Dependent Variable: LOM

The result was interpreted as follow:

$$
\begin{aligned}
& \mathrm{Y} \quad=\alpha+\mathrm{b} 1 \mathrm{JK} \ldots \ldots \ldots \ldots \ldots \ldots \\
& \mathrm{LOM}=60,450+4,650 \mathrm{JK}+\mathrm{e}
\end{aligned}
$$

\section{T test (Model Structure II)}

$\mathrm{T}$ test was used to determine the effect of partially independent variable on the dependent variable. In this study is the effect of gender toward the love of money. There was a significant value $t$ of each variable on the output of SPSS with significance level $0.05(\alpha=5 \%)$. Based on Table 13, the value of the gender significance was 0.000 . When it compared with the value of 0.05 then the value was smaller $(0.000<0.05)$. This meant that the $\mathrm{H} 5 \mathrm{~b}$ was accepted, the gender affect the the love of money.

\section{The coefficient of determination test $\left(R^{2}\right)$}

The coefficient of determination is analyzed to see how far the model's ability to explain variations in the dependent variable. According to the table 14 adjusted R-square of 0.207 indicates that $20.7 \%$ variation in the the love of money can be explained by gender while the remaining $79.3 \%$ is explained by variables outside the model studied.

Table 14. The coefficient of determination test (structure II)

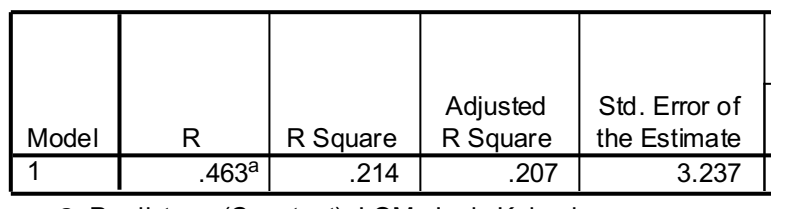

a. Predictors: (Constant), LOM, Jenis Kelamin

b. Dependent Variable: MCV 


\section{DISCUSSIONS}

The result of path analysis that was empirically taken from the students showed that the machiavellian behavior could be an intervening variable or mediation between the love of money and the unethical behavior. This result was in line with the research of Hegarty and Sims (1987) and Tang and Chiu (2003). The relation was formed from the direct effect of the love of money toward the unethical behavior and indirect effect of machiavellian toward the unethical behavior.

The students with high level of the love of money tend to show unsatisfactory performance because they will do many ways to achieve their goal without considering ethic code. Money is the root of criminal act (Tang et. al 2006) and greed of an individual (Tang and Chiu, 2003). Unsatisfactory performance is one of the machiavellian behavior. Machavellian behavior is reflected from the individual behavior which is related to money. An individual with high machiavellian tends to act aggressively and dishonest in achieving the goal, manipulate other to get good performance, and can convince other people but cannot be convinced. Machiavellian is centered to the three dimensions, they are violating and manipulating rule, acting cynical, and violating conventional moral.

The unethical behavior occurs from the low ethical perception of students. An accountant is a profession that is related to the money, so it is vulnerable to ethical violation. Money is a factor that motivate someone to work. In the work field, money is a reward for employee contribution. It means that money is a reward of service that has been done by employee (Hasibuan, 2007)

There are many factors affect the ethical perception of individu. Based on organization theory, individual perception is affected by the individual, environment, and perceived object (Robbins and Judge, 2008). The individual factor is the love of money which is the subjectivity of individu upon money. That is why, the students with high level of the love of money tend to conduct unethical behavior.

An individual with the high level of the love of money considers money as the need and will be ambitious to get money through many ways. This action lead to the unethical behavior. The result of this study is in line with the finding of Giacalone (2004) that the content of business education adopted by the students lead them to take manipulative act, provocative materialistic act, and the unethical behavior

The students who has high machiavellian tend to do the unethical behavior due to the high level of the love of money. On the contrary, the students who has low machiavellian will 
not do the unethical behavior due to the low level of the love of money. This result is in line with Tang et. al (2006) that the love of money is learned through socialization process in the childhood and maintained in the adulthood. Tang et. al (2006) also say that there was a significant effect between the love of money and the unethical behavior.

Gender affects the unethical behavior. Based on Gillgan (1982) and Richmond (2001), male and female has different way in evaluating ethical dilemma. Male tend to do unethical behavior because they are more focus to the success in competing. While female has better focus to achieve their goal without violating the rules.

This finding is in line with the finding of Muthmainah (2006) that there is a difference value between male and female in responding to the moral dilemma that leads to the unethical behavior. Female typically will be associated with the communal value, such as caring to other, does not prioritize herself, and desire to be a part of community. While male typically will be associated with self-improvement, self-actualization, and competition. It means that female will think firmly about ethical behavior and tend to dodge the unethical behavior.

Hartanto (2001) revealed that there was a strong and consistent relation between moral consideration and gender. Female had stronger moral consideration than male. Female tended to be careful and try not take a risk that would harm her. While male tended to take a risk. This shows that gender affects the unethical behavior.

The empirical result showed that there was a positive relation between gender and the love of money behavior. This result was in line with Tang et. al (2000) which showed that female tended to less attentive toward money compare to male. It was because female was not motivated to get power and authority as long as their need was fulfilled. Due to the lack of motivation, female could act more ethically compare to male. Male tended to violate the rule or regulations. This result shows that gender affects the love of money behavior.

The empirical result showed that there was a negative relation between gender and machiavellian behavior. Male tended to conduct machiavellian behavior than female. Male tend to be more ambitious than female, thus their probability to conduct machiavellian behavior is higher. Bui (2003) reveals that female tend to dodge from the unethical behavior or any other machiavellian behavior. Richmond (2001) explains that basic moral considerations between male and female are different, thus the machiavellian behavior is also different. Compare to male, female tend to have decisive attitude in taking decision (Lawrence and Shaub, 1997). 


\section{CONCLUSION}

In conclusion, machiavellian can be a mediation variable to affect the love of money toward ethical perception of students. The students with high level of machiavellian tend to do unethical behavior due to their high level of the love of money. On the contrary, the students with low level of machiavellian unlikely to do unethical behavior due to their low level of the love of money. Male students tend to take a risk in act compare to female, so in this study gender as demographic variable also affects the relation between the love of money and the unethical behavior.

For the suggestion, there should be some efforts to change the mindset of students not to be money-oriented in doing their work. Since the high level of the love of money can lead to the unethical behavior. The level of unethical behavior will increase if the students tend to have machiavellian behavior. The effort can be done by incorporating ethic code in learning process and involving the students in organization or community service. This study used undergraduate students as the subject of study, so the future research can used graduate students or an accountant in a company. The future researcher can also change the demograhic variable or other mediation variable, such as economic status or family background to analyze the effect of the love of money toward the unethical perception.

\section{REFFERENCES}

Aziz, T.I dan A.Taman. (2015). Pengaruh Love of Money dan Machiavellian Terhadap Persepsi Etis Mahasiswa Akuntansi. Jurnal Nominal. Vol. IV No.2. Universitas Negeri Yogyakarta.

Basri, Yesi.M. (2015). Pengaruh Gender, Religiusitas dan Sikap Love of Money Pada Persepsi Etika Penggelapan Pajak Mahasiswa Akuntansi. Jurnal Ilmiah Akuntansi dan Bisnis. Vol.10 No.1. Fakultas Ekonomi Universitas Riau.

Beu, D.S., Buckley, M.R., \& Harvey, M.G. (2003). Ethical Decision-making: A Multidimensional construct. Bussiness Ethics: A European Review, 12(1), 1-3.

Charismawati, Celvia D. (2011). Analisis Pengaruh Love of Money Terhadap Persepsi Etis Mahasiswa Akuntansi. Skripsi. Fakultas Ekonomi Universitas Diponegoro.

Chen, Y.J., and Tang, T.L.P. (2006). Attitude toward and propensity to engage unethical behavior: Measurement invariance across major among university studnets. Journal of Business Ethics, 69(1), 77-93

Chrsitie, R and Geis, F.L. (1970). Studies in Machiavellianism (p.106). New York: Academic Press. 
Elias, R.Z. dan Farag, M.S. (2010). The Relationship Between Accounting Students' Love of Money and Ethical Perception. Managerial Auditing Journal. Vol.25. Iss.3. pp. 269281.

Fuad, Ratih Y. (2013). Love of Money, Ethical Reasoning, Machiavellian, Questionable Actions: The Impact on Accounting Students' Ethical Decision Making by Gender Moderation. Diponegoro Journal of Accounting. Vol.2 No.3 hal. 1-11. Universitas Diponegoro.

Furnham, A. (1984). Many sides of the coin: The psychology of money usage. Personality and individual differences, 5(5), 501-509.

Gendro, Wiyono. (2011). Merancang Penelitian Bisnis dengan Alat Analisis SPSS dan Smart PLS. Yogyakarta: UPP STIM YKPN

Giancalone, R.A. (2004). A Trancendent Business Education for the $21^{\text {st }}$ century. Academy of Management Learning \& Education. 3(4), 415-420.

Griffin, R dan Ebert, R.J. (2006). Business. Edisi ke delapan. Jakarta: Airlangga.

Hasibuan, Malayu. (2011). Manajemen Sumber Daya Manusia. Edisi Revisi. Jakarta: Bumi Aksara

Hegarty, W.H., \& Sims, H.P. (1978). Some Determinant of Unethical Decision Behavior: An Experiment. Journal of Applied Psycology, 63(4), 451-457.

Hermawan, S dan W.Nurlia. (2016). Dapatkah Love of Money Sebagai Variabel Intervening Pengaruh Variabel Kecerdasan Terhadap Persepsi Mahasiswa Akuntansi?. Jurnal Ilmiah Akuntansi dan Bisnis. 121-150

Keraf, A. Sonny. (1998). Etika Bisnis, Tuntutan, dan Relevansinya. Yogyakarta: Kanisius.

Marwanto. (2007). Pengaruh Pemikiran Moral, Tingkat Idealisme, Tingkat Relativisme dan Locus of Control terhadap Sensitivitas, Pertimbangan, Motivasi dan Karakter Mahasiswa Akuntansi (Studi Eksperimen pada Politeknik Negeri Samarinda). Tesis. Universitas Diponegoro.

Mitchell, T.R.Dakin.,S.,Mickel.,A., and Gray,S. (1998). The measurement of money importance. Paper Presented at the Annual Meeting of the Academy of Management, San Diego.

Moore, C., Detert,J.R, Klebe Trevino, L, Baker, V.L and Mayer, D.M. (2012). Why Employees Do Bad Things: Moral Disengagement and Unethical Organization Behavior. Personal Psycology, 65(1), 1-48.

Murtanto dan Marini. (2003). Persepsi akuntan Pria dan akuntan Wanita serta Mahasiswa dan Mahasiswi terhadap Etika Bisnis dan Etika Profesi. Simposium Nasional Akuntansi (SNA) VI. Surabaya: 16-17 Oktober.

Muthmainah, S. (2006). Studi tentang Perbedaan Evaluasi Etis, Intensi Etis, dan Orientasi Etis dilihat dari Gender dan Disiplin Ilmu: Potensi Rekruitmen Staf Profesional pada Kantor Akuntan Publik. Simposium Nasional Akuntansi IX, Padang. 
Normadewi, Berliana. (2012). Analisis Pengaruh Jenis Kelamin dan Tingkat Pendidikan Terhadap Persepsi Etis Mahasiswa Akuntansi dengan Love of Money sebagai Variabel Intervening. Skripsi. Fakultas Ekonomi dan Bisnis Universitas Diponegoro.

Pekdemir, I.M dan A.Turan. (2015). The Relationship Among Love of Money, Machiavellianism and Unethical Behavior. Canadian Social Science. Vol. 11 No.6. pp.48-59.

Pradanti, N.R. dan A. Prastiwi. (2014). Analisis Pengaruh Love of Money Terhadap Persepsi Etis Mahasiswa Akuntansi. Diponegoro Journal of Accounting. Vol.3 No.3 hal. 1-12.

Richmond, K.Ann. (2001). Ethical Reasoning, Machiavellian Behavior, and Gender: the Impact on Accounting Student. Ethical Decision Making.

Richmond, K.Ann. (2003). Ethical Reasoning, Machiavellian Behavior, and Gender: the Impact on Accounting Students' Ethical Decision Making. Dissertition. Virginia Polytechnic Institute.

Robbins and Judge. (2008). Perilaku Organisasi.terj: Diana Angelica. Jakarta: Salemba Empat.

Sugiyono. (2012). Metode Penelitian Bisnis. Bandung: CV Alfabeta

Tang, T. L. P. (1992). The meaning of money revisited. Journal of Organizational Behavior, 13(2), 197-202.

Tang, T.L.P. (1995). The Development of A Short Money Ethic Scale: Attitude Towards Money and Pay Satisfaction Revisited. Personality and Individual Differences. Vol.19 No. 6. pp. 809-816.

Tang, T. L.-P., Kim, J. K., \& Tang, D. S.-H. (2000). Does attitude toward money moderate the relationship between intrinsic job satisfaction and voluntary turnover? Human Relations, 53(2), 213-245. https://doi.org/10.1177/0018726712465095

Tang, T.L.P and Chiu, R.K. (2003). Income, Money Ethic, Pay Satisfaction, Commitment, and Unethical Behavior: Is Love of Money the Root of Evil for Hong Kong Employees?. Journal Business Ethics. Vol.46. No.1.pp 13-30.

Tang, T.L.P., Tang, T.L.N and Homaifar, B.Y. (2006). Income, The Love of Money, Pay Comparison, and Pay Satisfaction: Race and Gender as Moderation. Journal of Managerial Psycology. Vol 21.No.5.pp. 476-491.

Tang, T.L.P and Chen, Y.J. (2008). Intelegence vs Wisdom: The Love of Money, Machiavellianism and Unethical Behavior Across College Major and Gender. Journal of Business Ethics. Vol. 82.No.1. pp.1-26.

Tang, T.L.P., Chen, Y.J, and Sutarso, T. (2008). Bad Apples in Bad (Business) Barrels. The Love of Money, Machiavellianism, Risk Tolerance and Unethical Behavior. Management Decision. Vol 46. No.2.pp.243-263.

Valentine, S., and Fleischman, G. (2003). The impact of self-esteem, Machiavellianism, and social capital 108 II. Interpersonal Dispositions on attorneys' traditional gender outlook. Journal of Business Ethics, 43, 323-335. 
Vardi, Y., \& Wiener, Y. (1996). Misbehavior in organization: A motivational framework. Organization Science, 7(2), 151-165.

Wouters, K., Maesschalck, J., Peeters, C.F., and Roosen, M. (2014). Methodological issues in the design of online surveys for measuring unethical work behavior: recommendations on the basic of a split-ballot experiment. Journal of Business Ethics. 120 (2), 275-289. 